Revista Latinoamericana de la Papa 23 (2): 39 - 45, 2019

ISSN: 1853-4961

http://ojs.papaslatinas.org/index.php/rev-alap/index

\title{
New genotypes as alternative to expand the potato cultivation period in the Brazilian Midwest
}

\section{G.E. Pereira ${ }^{1}$, J. Zucolotto ${ }^{2}$, C.F. Ragassi ${ }^{3}$, C.A. Lopes, A.D. Ferreira de Carvalho}

Received: $24 / 11 / 2019$

Accepted: 05/12/2019

Accessible on line: December 2019

\section{Summary}

The climatic conditions of the Brazilian Midwest restrict potato cultivation to periods of the year when air moisture is lower and temperatures warmer. Thus, potato planting is restricted to the months of April and May, which provides the plants ideal conditions of development in a period of greater susceptibility to Ralstonia spp. (Rs), which presents better development in conditions of high temperature. This work aimed to evaluate the adaptation of Embrapa's potato genotypes to the edaphoclimatic conditions of the Federal District Region planted out of the main planting season. Two experiments were carried out in Brasília, DF, at different planting dates in 2017 and 2018. The complete randomized blocks experimental design was used with three replications in 2017 and four replications in 2018. Genotypes F183-08-01, F50-08-01, BRSIPR Bel, Agata, Atlantic and Asterix were evaluated in both years. Clones 24-09, 29-19 and 30-09 were added in 2018. Plant vigor was evaluated by scores ranging from 1 to 5. SAS software was used in all analyzes. Production of marketable tubers of genotype 30-09 was higher than all other genotypes evaluated $\left(25,10 \mathrm{t} \mathrm{ha}^{-1}\right)$ under conditions favorable to Rs development. Clone 30-09 performed well and may be a potential genotype for increasing the potato-planting window in the Brazilian Midwest, especially when there is a history of Rs occurrence.

Additional Keywords: Solanum tuberosum, heat tolerance, mass of marketable tubers, total mass of tubers

\section{Nuevos genotipos como alternativa para expandir el período de cultivo de papa en el medio oeste brasileño}

\section{Resumen}

Las condiciones climáticas del Medio Oeste brasileño restringen el cultivo de la papa a períodos del año en que la humedad del aire es más baja y las temperaturas más cálidas. Por lo tanto, la siembra de papa está restringida a los meses de abril y mayo, lo que proporciona a las plantas las condiciones ideales de desarrollo en un período de mayor susceptibilidad a

* Corresponding author: E-mail. carlos.ragassi@embrapa.br

1 Universidade de Brasília, Faculdade de Agronomia e Medicina Veterinária, Brasília, Distrito Federal, Brazil, gb.emiliano28@gmail.com

2 Universidade de São Paulo, Programa de Pós-graduação em Fitotecnia, Piracicaba, São Paulo, Brazil, julianazucolotto@gmail.com

${ }^{3}$ Embrapa Hortaliças, Brasília, Distrito Federal, Brazil, carlos.lopes@embrapa.br, agnaldo.carvalho@embrapa.br

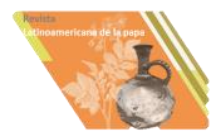


Ralstonia spp. (Rs), que presenta un mejor desarrollo en condiciones de alta humedad del aire y temperatura. Este trabajo tuvo como objetivo evaluar la adaptación de los genotipos de papa de Embrapa a las condiciones edafoclimáticas de la Región del Distrito Federal (DF) plantadas fuera de la principal temporada de siembra. Se realizaron dos experimentos en Brasilia, DF, en diferentes fechas de siembra en 2017 y 2018. El diseño experimental de bloques aleatorios completos se utilizó con tres repeticiones en 2017 y cuatro repeticiones en 2018. Genotipos F183-08-01, F50-08-01, BRSIPR Bel, Agata, Atlantic y Asterix fueron evaluados en ambos años. Los clones 24-09, 29-19 y 30-09 se agregaron en 2018. El vigor de la planta se evaluó mediante puntajes que varían de 1 a 5. Se utilizó el software SAS en todos los análisis. La producción de tubérculos comercializables del genotipo 30-09 fue mayor que todos los demás genotipos evaluados $\left(25,10 \mathrm{t} \mathrm{ha}^{-1}\right)$ en condiciones favorables para el desarrollo de Rs. El clon 30-09 funcionó bien y puede ser un genotipo potencial para aumentar el período en el cual es posible cultivar la papa en el Medio Oeste brasileño, especialmente cuando hay un historial de ocurrencia de Rs.

Palabras clave adicionales: Solanum tuberosum, tolerancia al calor, masa de tubérculos comercializables, masa total de tubérculos.

\section{Introduction}

Potato (Solanum tuberosum L.) was introduced in the European continent in the 16th century, afterwards becoming one of the most consumed vegetables in the world (FAO, 2008). It is cultivated in Brazil mainly in South and Southeast Regions and in some counties of the Brazilian Midwest and Northeast Regions (IBGE, 2018). Goiás State and Federal District, in the Brazilian Midwest, cultivate the potato mainly in the fall and winter seasons, being the planting restricted to the months of April and May, when climatic conditions are ideals for the crop development (Heldwein et al., 2009).

Potato is a very susceptible crop to Ralstonia spp. $(R s)$, pathogen that causes bacterial wilt (BW) (Takatsu and Lopes, 1997), when grown in the spring and summer seasons in the Brazilian Midwest. $R s$ is described as one of the most destructive phytopathogens in the world, causing production losses equivalent to US \$950 million per year worldwide (Lima Neto, 2005). The full development of $R s$ occurs under temperatures between $24^{\circ} \mathrm{C}$ and $35^{\circ} \mathrm{C}$ during the day and temperatures higher than $20^{\circ} \mathrm{C}$ during the night (Takatsu and Lopes, 1997), which does not occur during winter season in the Brazilian Midwest (INMET, 2018). Therefore, the planting season in the Brazilian Midwest is very restricted, with reflex in its contribution to the national potato production, of only 5.5\% (IBGE, 2018).

The cultivars predominantly planted in Brazil ('Agata' for the fresh market and 'Asterix' for industrial purposes) were developed in Europe. These cultivars were selected in climatic conditions very contrasting in relation to the Brazilian conditions, which made them poorly adapted for cultivation in the tropical region (Silva et al., 2014).

When selection of potato genotypes is carried out in tropical regions, which are characterized by high pressure of pests and pathogens, it indirectly selects genotypes with some level of resistance to pests and diseases (Lopes and Boiteux, 2016). Thus, the evaluation of adaptability of new genotypes, such as the potato genotypes of Embrapa's breeding program, to edaphoclimatic conditions of the producing region of the Brazilian 
Midwest, may provide indication of genotypes capable of increasing the cultivation of potato in this region.

This research had the objective of evaluating the adaptation of potato genotypes of Embrapa's breeding program to the edaphoclimatic conditions of Federal District planted in the conventional season of cultivation and in late season, aiming at the indication of genotypes capable of increase the cultivation of potato in Brazilian Midwest, mainly in relation to the incidence of bacterial wilt.

\section{Materials and methods}

Two experiments were carried out in two years in Embrapa Vegetables experimental fields $\left(15^{\circ} 55^{\prime} 43,87 \mathrm{~S} ; 48^{\circ}\right.$ 08' 35,32 W; Alt. $1000 \mathrm{~m}$ ), Brasília, Federal District, Brazil. Climate is Aw (humid tropical climate with dry winter and warm summer according to KöppenGeiger's classification). Rainy season occurs between October and April, with 1,477.4 $\mathrm{mm}$ average annual precipitation, average daily highest and lowest temperatures of $16,8^{\circ} \mathrm{C}$ and $26,6^{\circ} \mathrm{C}$, respectively, with the higher annual temperatures historically registered in September.

The soil, classified as clayey orthox (USDA, 1999), was kept in fallow for 10 years and plowed once then diskharrowed twice before implementing the experiment. Chemical analysis $(0-0.2$ $\mathrm{m})$ presented $\mathrm{pH}\left(\mathrm{H}_{2} \mathrm{O}\right): 5,2 ; \mathrm{P}_{\text {(Mehlich) }}, \mathrm{K}$, $\mathrm{Na}, \mathrm{B}, \mathrm{Cu}, \mathrm{Fe}, \mathrm{Mn}, \mathrm{Zn}$ and $\mathrm{S}=1,0 ; 462,0$; 17,$0 ; 0,03 ; 2,2 ; 31,0 ; 40,4 ; 4,4$ and $2,0 \mathrm{mg}$ $\mathrm{dm}^{-3}$, respectively; $\mathrm{Ca}, \mathrm{Mg}, \mathrm{Al}$ and $\mathrm{H}+\mathrm{Al}$ $=4,6 ; 0,7 ; 0,0$ and $6,2 \mathrm{cmol}_{\mathrm{c}} \mathrm{dm}^{-3}$, respectively and O.M. $=33,7 \mathrm{~g} \mathrm{dm}^{-3}$. Fertilizing was carried out at planting with $120 \mathrm{~kg} \mathrm{ha}^{-1} \mathrm{~N}, 900 \mathrm{~kg} \mathrm{ha}^{-1} \mathrm{P}_{2} \mathrm{O}_{5}, 480$ $\mathrm{kg} \mathrm{ha}^{-1} \mathrm{~K}_{2} \mathrm{O}$ and $15 \mathrm{~kg} \mathrm{ha}^{-1} \mathrm{Zn}$ and sidedressing fertilization with $90 \mathrm{~kg} \mathrm{ha}^{-1} \mathrm{~N}$ at the moment of the final ridge was made, 22 days after planting (DAP). Planting was carried out into furrows on May 29, 2017 and June 16, 2018, spaced 0,8 m between lines and 0,35 between plants.

The complete Randomized Blocks experimental design was used in both years. Six treatments with three replications were used in 2017 and nine treatments with four replications in 2018. The experimental plots consisted of 15 plants, which occupied an area of 4,2 $\mathrm{m}^{2}$. The advanced clones F183-08-01 and F50-08-01 and the cultivars BRSIPR Bel, Agata, Atlantic and Asterix were evaluated in both years. The clones 2409, 29-19 and 30-09 were added in 2018 because of their good performances in fields infested with BW.

Irrigation and phytosanitary management were done according to the crop recommendations (Silva and Lopes, 2016). The vigor of the plants was evaluated by a scale of visual grades at 50 DAP, being: $5=$ high vegetative vigor, 4 $=$ medium-high vigor, $3=$ medium vigor, $2=$ medium-low vigor and $1=$ low vigor (CIP, 2009). The crops were harvested with a semi-mechanized potato harvester on September 18, in 2017 and November 5, in 2018 (112 DAP). Total mass of tubers (TM), mass of marketable tubers (MM), number of marketable tubers (NM) and average individual tubers mass (AM) were obtained by weighing and counting and it were transformed for production per hectare according to the number of emerged plants at 30 DAP.

Residue normality and homogeneity were calculated with data transformed into square root of $(\mathrm{x})$. Joint analysis of transformed data for the common genotypes in the two years was made to compare planting periods. An analysis of variance was made to compare the new 
genotypes added in 2018. Tukey test $(\mathrm{p}<0,05)$ was used in experimental analyses of joint analysis and Scott-Knott test $(\mathrm{p}<0,05)$ was used in experimental analysis of 2018. The SAS software was used to make all the analysis.

\section{Results and discussion}

The evaluated potato genotypes showed differences among each other in the two years of evaluation regarding total and marketable yield of tubers (TM and MM), number of marketable tubers (NM) and average individual tuber mass (AM) (Table 1). In addition, the overall mean of these genotype characteristics in the two years of evaluation was statistically different $(\mathrm{p}<0,001)$. This difference may have occurred due to the late planting period in 2018 which exposes the plants to air moisture and temperature that favor the development of Rs (Takatsu and Lopes, 1997) and, consequently, reduced the overall genotype average in 2018 . According to the joint analysis of the two years of evaluation, there was no significant interaction between the year and genotype factors. Thus, the performance of the genotypes observed through the evaluated variables was similar in the different evaluation years, that is, the genotypes that presented superior performance in 2017 maintained the superiority in 2018.

Table 1. Joint analysis of 2017 and 2018 for total mass of tubers (TM, $\mathrm{t} \mathrm{ha}^{-1}$ ), mass of marketable tubers $\left(\mathrm{MM}, \mathrm{t} \mathrm{ha} \mathrm{h}^{-1}\right)$, number of marketable tubers $\left(\mathrm{NM}, \mathrm{ha}^{-1}\right)$ and average individual tuber mass (AM).

\begin{tabular}{lrrrr}
\hline Cultivar & \multicolumn{1}{c}{ TM } & \multicolumn{1}{c}{ MM } & NM & AM \\
\hline Agata & $18,66 \mathrm{a}$ & $12,59 \mathrm{a}$ & $74693,38 \mathrm{a}$ & $0,17 \mathrm{ab}$ \\
Asterix & $11,37 \mathrm{ab}$ & $9,05 \mathrm{ab}$ & $55905,45 \mathrm{ab}$ & $0,16 \mathrm{ab}$ \\
Atlantic & $14,04 \mathrm{ab}$ & $10,88 \mathrm{ab}$ & $65369,79 \mathrm{a}$ & $0,14 \mathrm{~b}$ \\
BRSIPR Bel & $14,34 \mathrm{ab}$ & $9,62 \mathrm{ab}$ & $68168,56 \mathrm{a}$ & $0,13 \mathrm{~b}$ \\
F183-08-01 & $19,40 \mathrm{a}$ & $16,00 \mathrm{a}$ & $65757,13 \mathrm{a}$ & $0,24 \mathrm{a}$ \\
F50-08-01 & $7,53 \mathrm{~b}$ & $5,97 \mathrm{~b}$ & $25991,91 \mathrm{~b}$ & $0,15 \mathrm{ab}$ \\
\hline General average & 14,22 & 10,69 & 59314,37 & 0,16 \\
Average 2017 & 19,95 & 16,80 & 79758,90 & 0,22 \\
Average 2018 & 8,42 & 4,27 & 35591,06 & 0,11 \\
\hline F test for: & & & & \\
Cultivar (C) & $5,76 * *$ & $5,95 * *$ & $4,15 * *$ & $3,39 *$ \\
Years (Y) & $52,38 * * *$ & $115,81 * * *$ & $23,58 * * *$ & $45,40 * * *$ \\
C x Y & $0,92 \mathrm{~ns}$ & $1,89 \mathrm{~ns}$ & $0,86 \mathrm{~ns}$ & $2,59 \mathrm{~ns}$ \\
CV\% & 18,53 & 17,89 & 25,78 & 3,89 \\
\hline
\end{tabular}

Means followed by the same lowercase letters in the columns do not differ by Tukey test at $5 \%$ probability. ns: not significant, $*$ : significant at $5 \%$ probability, $* *$ : significant at less than $1 \%$ probability and $* * *$ : significant at less than $0,1 \%$ probability.

F183-08-01 and Agata produced total and marketable tuber mass higher than F5008-01 (Table 1). However, these two genotypes showed similar production to the other control genotypes (Asterix and Atlantic). Production of these potato 
genotypes in the experiments performed in both years was lower compared to their production (> 31,63 t ha-1) under ideal cultivation conditions as reported by Bortoletto and Silva (2016) demonstrating the importance of developing specific potato varieties for each growing season in the Brazilian Midwest region.

F183-08-01 presents desirable shape, size and physicochemical qualities for french fries processing as well as Asterix (Fernandes et al. 2010). The average mass of individual tubers of the F183-0801 confirms its suitability for this purpose by presenting tuber size similar to Asterix and larger than Atlantic and BRSIPR Bel whose purpose is industrial chip processing (Pereira et al., 2015), as can be observed by AM (Table 1). Number of marketable tubers was similar for all evaluated genotypes with exception of F50-08-01. Thus, Agata, Atlantic, BRSIPR Bel and F183-08-01 produced more tubers per area than F50-08-01.

The average yield of tubers in the 2018 experiment (Table 1) obtained from the ratio of marketable to total tubers is approximately $50 \%$, which is considered low. In addition, total tuber production, as well as all other parameters evaluated, was over $50 \%$ lower in 2018 compared to 2017. Evaluated genotypes did not differ regarding plant vigor that varied from 3,17 to 4,67 for Atlantic and F183-08-01, respectively.

Table 2. Total mass of tubers (TM, $\left.t \mathrm{ha}^{-1}\right)$, mass of marketable tubers $\left(\mathrm{MM}, \mathrm{t} \mathrm{ha} \mathrm{a}^{-1}\right)$ and number of marketable tubers (NM, ha $\left.{ }^{-1}\right)$ of nine potato genotypes in 2018.

\begin{tabular}{|c|c|c|c|}
\hline Cultivar & TM & MM & NM \\
\hline $24-09$ & $9,84 \mathrm{~b}$ & $6,98 \mathrm{~b}$ & $51963,37 \mathrm{~b}$ \\
\hline $29-19$ & $2,47 \mathrm{c}$ & $0,31 \mathrm{~d}$ & $3062,84 \mathrm{c}$ \\
\hline $30-09$ & $25,10 \mathrm{a}$ & $14,34 \mathrm{a}$ & 99971,49 a \\
\hline Agata & $10,45 \mathrm{~b}$ & $4,44 \mathrm{~b}$ & $31456,29 b$ \\
\hline Asterix & $12,62 \mathrm{~b}$ & $5,89 \mathrm{~b}$ & $46823,18 b$ \\
\hline Atlantic & $8,47 \mathrm{~b}$ & $3,28 \mathrm{c}$ & $35506,10 \mathrm{~b}$ \\
\hline BRSIPR Bel & $6,69 \mathrm{~b}$ & $1,87 \mathrm{c}$ & $29558,08 \mathrm{~b}$ \\
\hline F183-08-01 & $9,87 \mathrm{~b}$ & $6,71 \mathrm{~b}$ & $44431,56 \mathrm{~b}$ \\
\hline F50-08-01 & $3,83 \mathrm{c}$ & $0,69 \mathrm{~d}$ & 5803,55 c \\
\hline Média geral & 9,93 & 4,95 & 38730,72 \\
\hline \multicolumn{4}{|l|}{ F test for: } \\
\hline Cultivar & $7,92 * *$ & $8,29 * *$ & $6,20 * *$ \\
\hline Blocks & $0,72 \mathrm{~ns}$ & $3,00 \mathrm{~ns}$ & $0,57 \mathrm{~ns}$ \\
\hline $\mathrm{CV} \%$ & 22,63 & 32,60 & 34,68 \\
\hline
\end{tabular}

Means followed by the same lowercase letters in the columns do not differ by Scott-knott test at $5 \%$ probability. ns: not significant and $* * *$ : significant at less than $0,1 \%$ probability.

Potato clones 24-09, 29-09 and 30-09 from Embrapa's breeding program were added to the 2018 experiment to evaluate their late cultivation performance (Table
2). Clone 30-09 was superior to all other genotypes evaluated in relation to all traits evaluated (TM, MM and NM). As observed in the combined analysis of the 
experiments (Table 1), clone F50-08-01 had one of the worst performances in 2018 when analyzed alone (Table 2).

\section{Conclusions}

The development of conventional potato cultivars as well as those developed for the ideal period of cultivation in the Brazilian Midwest is impaired when their cycle extends to spring, mainly due to the favoring of diseases such as BW. Under these conditions, clone 30-09 performed well and may be a potential genotype for increasing the potato planting window in the Brazilian Midwest, especially when there is a history of $\mathrm{BW}$ occurrence.

\section{Conflict of interest}

The authors declare no conflict of interest.

\section{Acknowledgments}

We thank Fernanda Quintanilha Azevedo, MSc, Arione Silva Pereira, $\mathrm{PhD}$ and Dr. Caroline Marques Castro and the Coordination of Superior Level Staff Improvement (CAPES), Organ of the Brazilian Ministry of Education.

\section{References}

Bortoletto, A. C. e Silva, G. O. (2016). Validação de Clones Avançados de Batata da Embrapa na Indústria. Batata Show - Associação Brasileira Da Batata 16(46): 52-55.

CIP. (2009). Procedimientos para pruebas de evaluación estándar de clones avanzados de papa.

FAO. (2008). Background. Retrieved October 11, 2018, from http://www.fao.org/potato2008/en/aboutiyp/background.html

Fernandes, A. M., Soratto, R. P., Evangelista, R. M., \& Nardin, I. (2010). Qualidade físico-química e de fritura de tubérculos de cultivares de batata na safra de inverno. Horticultura Brasileira, 28(3), 299-304. https://doi.org/10.1590/S010205362010000300010

Heldwein, A. B., Streck, N. A., Bisognin, D. A. (2009). Batata. In J. E. B. A. Monteiro (Ed.), Agrometeorologia dos Cultivos: $O$ fator meteorológico na produção agrícola (1st ed., pp. 93-108). Brasília, DF: INMET.

IBGE. (2018). Sistema IBGE de recuperaçãoo automática: SIDRA. Banco de dados agregados. Retrieved October 16, 2018, from https://sidra.ibge.gov.br/pesquisa/lspa/tab elas

INMET. (2018). Estações Automáticas. Retrieved September 14, 2018, from http://www.inmet.gov.br/portal/index.php $? \mathrm{r}=$ estacoes/estacoesautomaticas

Lima Neto, A. F. (2005). Avaliação da resistência de clones e cultivares de batata à murcha bacteriana (Ralstonia solanacearum). Universidade de Brasília.

Lopes, C. A. e Boiteux, L. S. (2016). Melhoramento Genético Visando Resistência à Murcha Bacteriana. In M. A. S. da Gama, A. Nicoli, L. M. P. Guimarães, U. P. Lopes, S. J. Michereff (Eds.), Estado da Arte em Fitobacterioses Tropicais (pp. 257-274). Recife: EDUFRPE.

Pereira, A. S., Nazareno, N. R. X., Silva, G. O., Bertoncini, O., Castro, C. M., Hirano, E., Melo, P. E. (2015). BRSIPR Bel: Cultivar de batata para chips com tubérculos de boa aparência. Horticultura Brasileira 33(1): 135-139.

Takatsu, A. e Lopes, C. A. (1997). Murcha-bacteriana em hortaliças: avanços científicos e perspectivas de controle. Horticultura Brasileira 15(061): 170-177. 
USDA. (1999). Soil Taxonomy: A Basic System of Soil Classification for Making and Interpreting Soil Surveys (2nd ed.).
Washington, DC: United States

Department of Agriculture (USDA). 